\title{
ESTROGEN RECEPTORS IN HUMAN VAGINAL TISSUE
}

\author{
M.A.H.M. WIEGERINCK ${ }^{2}$, ${ }^{*}$ J. POORTMAN ${ }^{1}$, A.R. AGEMA ${ }^{1}$ and J.H.H. THIJSSEN ${ }^{1}$ \\ ${ }^{1}$ Department of Endocrinology and ${ }^{2}$ Department of Obstetrics and Gynecology, University \\ Hospital State University Utrecht, 3500 GC Utrecht, The Netherlands
}

(Received 20 September 1979; accepted 12 October 1979)

The presence of specific estrogen receptors could be demonstrated in vaginal tissue, obtained during operation from 38 women, age $27-75$ yr.

In 23 premenopausal women the receptor concentration in the vaginal tissue varied between 12 and $91 \mathrm{fmol} / \mathrm{mg}$ protein, no significant difference in the receptor level was found between the proliferative and secretory phase of the menstrual cycle, classified by endometrial histology.

In 15 postmenopausal patients, the receptor level varied between 4 and $119 \mathrm{fmol} / \mathrm{mg}$ protein. In the last group a significant negative correlation $(R=-0.72)$ was found between the vaginal estrogen receptor level and the Maturation Value of the vaginal smear; no correlations were found between the receptor level and the plasma levels of estrone, estradiol, LH, FSH and SHBG.

No systematic differences in the receptor concentration in various parts of the vagina were observed. There was no correlation between the receptor level and age of the patients.

(Key words: Estrogen receptors, Vagina, Estrogen action)

\section{INTRODUCTION}

The human vagina is an organ highly sensitive for estrogens. An essential step in the chain of events, leading to estrogenic effects is the binding of estrogens to specific intracellular proteins, called receptors. Estrogen receptors have been demonstrated in human endometrium and myometrium in recent years [1-5], but to our knowledge, no data on the presence of estrogen receptors in human vaginal tissue have been published. Therefore a study was designed to answer the following questions:

1. Does vaginal tissue contain specific estrogen receptors?

2. If so, what is the concentration of vaginal estrogen receptor in relation to: age; phase of the menstrual cycle in premenopausal women; estrogenic parameters (Maturation Index and Maturation Value) and plasma levels of estrone and estradiol in postmenopausal women.

* To whom requests for reprints should be sent.

Abbreviations: $E_{1}$ : Estrone, $E_{2}$ : Estradiol, LH: Luteinizing hormone, FSH: Follicle stimulating hormone, SHBG: Sex hormone binding globuline. 


\section{MATERIALS AND METHODS}

\section{Patients}

Thirty-eight women, age 27-75 yr, admitted to the Department of Gynecology of the University Hospital at Utrecht, scheduled for cystocele or rectocele repair operation or hysterectomy, participated after informed consent in this study. They used no medication and had no other (relevant) illness.

\section{Steroids}

1,2,6,7- $\left[{ }^{3} \mathrm{H}\right]$ estradiol (S.A. $85-108 \mathrm{Ci} / \mathrm{mmol}$ ) was purchased from The Radiochemical Centre, Amersham, U.K. Purity $(>98 \%$ ) was regularly checked by thin layer chromatography. Unlabelled estradiol was obtained from Makor Chemicals (Ramat Gan, Israel). The anti-estrogen nafoxidine (U 11.100) was a gift from Upjohn Company, Ede, The Netherlands. Dextran T70 and Sephadex LH-20 were purchased from Pharmacia, Sweden; Norit A (Aktivkohle Reinst) and Sucrose for the sucrose-gradients from Merck, Darmstadt, West Germany. All other reagents were of analytical grade.

\section{Endogenous hormone levels}

One day prior to surgery a blood sample was drawn from the cubital vein for the determination of endogenous $\mathrm{E}_{1}, \mathrm{E}_{2}, \mathrm{FSH}$ and $\mathrm{LH}$ and sex hormone binding globulin (SHBG). Endogenous hormone levels were measured by radioimmunoassays with specific antisera. SHBG was measured as previously described [6]. Estrone and estradiol were purified and separated prior to assay by chromatography on Sephadex LH-20. The detection limit of the estrone and estradiol assay is about $5 \mathrm{pg} / \mathrm{ml}$.

\section{Cytohormonal studies}

For the cytohormonal assessment a smear with an ayer spatula was taken from the upper third of the lateral vaginal wall. Routine fixation and Papanicolaou staining was done. Of each cytological slide three hundred intact squaemous cells were counted and classified as parabasal, intermediate or superficial cells. The maturation index gives the number of parabasal, intermediate and superficial cells per one hundred cells. Proliferation of the vaginal epithelium under the influence of estrogens is reflected in the vaginal smear by an increase in intermediate and superficial cells. The maturation value is derived from the Maturation Index by attributing a score to each cell type. Parabasal cells have a value of zero, intermediate cells of one-half and superficial cells of one. The total sum after applying this score is defined as the Maturation Value [7]. This value shows an increase after estrogen stimulation.

\section{Tissue}

The operations wcre performed under general anaesthesia using standard procedures. The excess of vaginal mucosa was excised; part of it was immediately put on ice, transported to the laboratory and stored at $-70^{\circ} \mathrm{C}$ until processing. It is well established, that the estradiol receptor in unprocessed tissue is stable under these conditions for several weeks. As control tissue, normal human myometrium and endometrium were used. From five patients a strip of vaginal tissue was obtained to study possible differences in receptor 
concentration in various parts of the vagina. The amount of vaginal tissue processed varied between 0.06 and $1.10 \mathrm{~g}$ wet wt.

\section{Preparation of the extract}

Each tissue was kept at $4^{\circ} \mathrm{C}$ during processing. It was crushed in small parts, weighed and washed in cold Tris-buffer ( $10 \mathrm{mM}$ Tris-HCl, $1 \mathrm{mM}$ EDTA, $3 \mathrm{mM} \mathrm{NaN}_{3}, \mathrm{pH} 7.5$ ) and pulverized in a Micro-dismembrator (Braun, Melsungen, West Germany) after cooling in liquid nitrogen. The powder so obtained was suspended in cold Tris-buffer $(1: 4 \mathrm{w} / \mathrm{v})$. After mixing with a Vortex-mixer, a supernatant was prepared by ultracentrifugation at $30000 \mathrm{rpm}$ (about $100000 \times \mathrm{g}$ ) in a Beckman SW 50.1 rotor. The clear supernatant (cytosol) for the incubation studies was obtained by piercing the cellulose nitrate tube above the pellet without contamination with the upper fat layer.

For incubation, tritiated estradiol (4 concentrations from $3.10^{-10}$ to $2.10^{-9} \mathrm{M}$ ) was dissolved in $0.5 \mathrm{ml}$ of Tris-buffer. After thorough mixing, $0.5 \mathrm{ml}$ of the cytosol preparation was then added. After $18 \mathrm{~h}$ at $4^{\circ} \mathrm{C}$, the unbound estradiol was removed by dextran coated charcoal treatment $(1 \mathrm{ml}$ of suspension of $5 \mathrm{~g} / 1$ Norit A, $0.5 \mathrm{~g} / 1$ Dextran T70 and $1 \mathrm{~g} / 1$ gelatine in the buffer used for homogenization). In separate experiments it was shown that a $30 \mathrm{~min}$ exposure time to the dextran coated charcoal mixture removes bound $\left[{ }^{3} \mathrm{H}\right]$ estradiol from low-affinity binders, but does not strip $\left[{ }^{3} \mathrm{H}\right]$ estradiol from high affinity receptor sites. The labelled, bound steroid was counted. The data were analyzed according to Scatchard [8].

\section{Specificity}

To distinguish between specific receptor binding ("high affinity sites") and binding to SHBG and to albumin ("low affinity sites"), in each experiment parallel incubations were performed with 100-fold excess of cold $\mathrm{E}_{2}$ or a 1000 -fold excess of nafoxidine, as compared to the concentrations of labelled estradiol. Nafoxidine is a specific and very potent inhibitor of the binding of estradiol to its receptor, but does not inhibit the binding of estradiol to SHBG, albumin or other plasma constituents [9].

To characterize receptor bindings, incubations were applied to a sucrose gradient in an ultracentrifuge. After 2-6h of incubation, as described above, the unbound estradiol was removed by mixing with a $2000 \times g$ pellet from $1 \mathrm{ml}$ dextran coated charcoal suspension for $30 \mathrm{~min}$ and was then centrifuged for $10 \mathrm{~min}$ at $2000 \times \mathrm{g}$. Sucrose gradients $(10-40 \%)$ were prepared in Tris-buffer and $200 \mu$ of the incubated cytosols, after charcoal treatment, were added for centrifugation at $45000 \mathrm{rev} . / \mathrm{min}$ for $16 \mathrm{~h}$ in a Beckman SW 50.1 rotor, 40 fractions were collected from each centrifugation tube and counted in $10 \mathrm{ml}$ of the scintillator solution.

${ }^{14} \mathrm{C}$-labelled albumin, prepared according to Siiteri et al. [10], was added to each tube $(\approx 2000 \mathrm{dpm})$ to check the quality of the gradient and as a reference to establish the sedimentation value of individual peaks.

Liquid Scintillation Counting was done in a Packard 2425 Tricarb apparatus. The scintillation solution was $10 \mathrm{ml}$ of Instagel (Packard Instruments, Brussels, Belgium). Total tissue protein was determined by the method of Lowry et al. [11] with human serum albumin as a standard.

Details of all the techniques used have been described in recent publications $[9,12,13]$. 
Their usefulness in receptor studies in human uterine tissue and in human malignant mammary cancer tissue is well documented [14].

\section{RESULTS}

The presence of specific estrogen receptors could be demonstrated in the vaginal tissue of all 38 women studied. There was a wide variation in the concentrations of receptor sites: the lowest level found was $4 \mathrm{fmol} / \mathrm{mg}$ protein; the highest level $119 \mathrm{fmol} / \mathrm{mg}$ protein.

To characterize the binding sites, an 8-point-assay was done. This enabled us to correct for $\alpha$-specific binding and to analyse the data according to Scatchard. An example of such a Scatchard-plot of the vaginal cytosol estrogen receptor is shown in Fig. 1.

The number of binding sites in this case corresponds to $36 \mathrm{fmol} / \mathrm{mg}$ protein. The $K_{\mathrm{d}}$ value of $7.10^{-10} \mathrm{M}$ identifies high affinity receptor binding sites. In Figure 2 a sucrose gradient profile is given of a vaginal cytosol after incubation with $\left[{ }^{3} \mathrm{H}\right]$ estradiol. The estrogen-receptor sediments with a sedimentation value of about $4 \mathrm{~S}$. Only one peak for the binding of $\mathrm{E}_{2}$ could be detected. In the premenopausal women $(n=23)$ the estrogen receptor concentration in vaginal cytosol varied between 12 and $91 \mathrm{fmol} / \mathrm{mg}$ protein, with an average of $37 \mathrm{fmol} / \mathrm{mg}$ protein. Insufficient data on cytohormonal values and on plasma estrogens were available to correlate them with vaginal estrogen receptor levels. Of
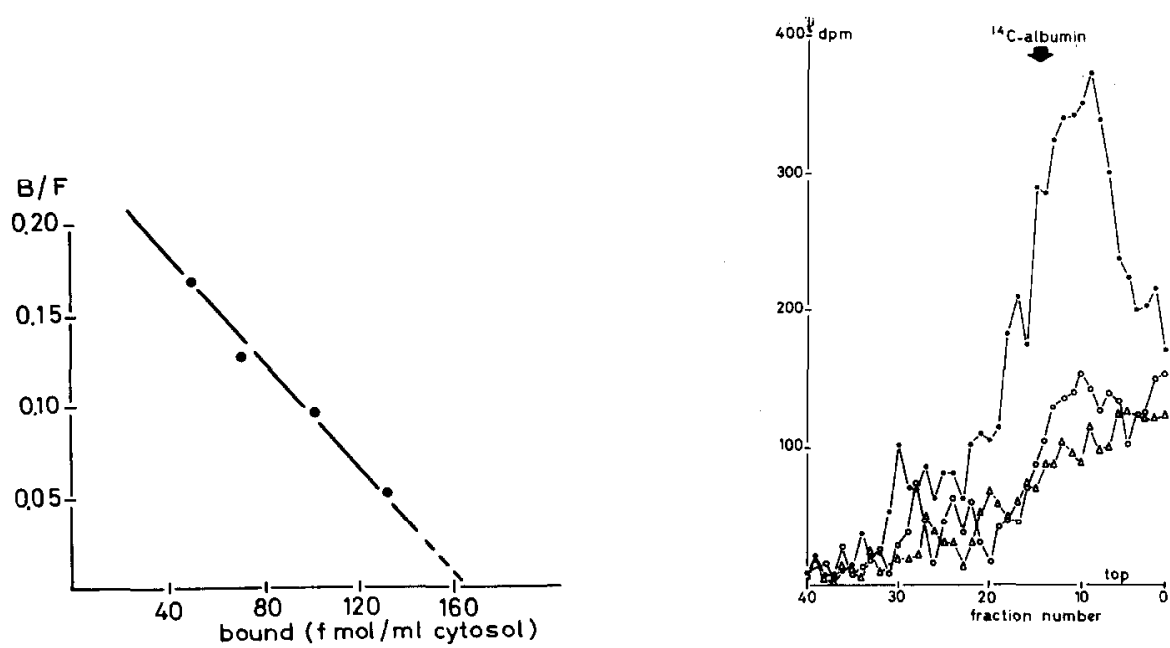

Fig. 1. Scatchard plot analysis of the binding of tritiated estradiol in cytosol of vaginal tissue. The data are corrected for $\alpha$-specific binding. The number of receptor sites are expressed as fmol per $\mathrm{ml}$ cytosol, corresponding with $36 \mathrm{fmol} / \mathrm{mg}$ protein. $n=36 \mathrm{fmol} / \mathrm{mg}$ protein, $K_{\mathrm{d}}=7 \times 10^{-10} \mathrm{M}$.

Fig. 2. Profile of a sucrose gradient $(10-40 \%)$ centrifugation $(16 \mathrm{~h}, 45000 \mathrm{rev} . / \mathrm{min}$, SW 50.1 rotor) after incubation with tritium-labelled estradiol. Parallel incubations with cold estradiol (100-fold excess) and nafoxidine (1000-fold excess), as described in the Materials and Methods section are also shown. The arrow: peak of $\left[{ }^{14} \mathrm{C}\right]$ radioactivity of human serum albumin on the gradient (about $4.6 \mathrm{~S}$ ). $\bullet,\left[{ }^{3} \mathrm{H}\right] \mathrm{E}_{2}, 2 \mathrm{nM} ; \circ,\left[{ }^{3} \mathrm{H}\right] \mathrm{E}_{2}, 2 \mathrm{nM}+200 \mathrm{nM} \mathrm{E} 2 ; \Delta,\left[{ }^{3} \mathrm{H}\right] \mathrm{E}_{2}, 2 \mathrm{nM}+2000 \mathrm{nM} \mathrm{NaF}$. 


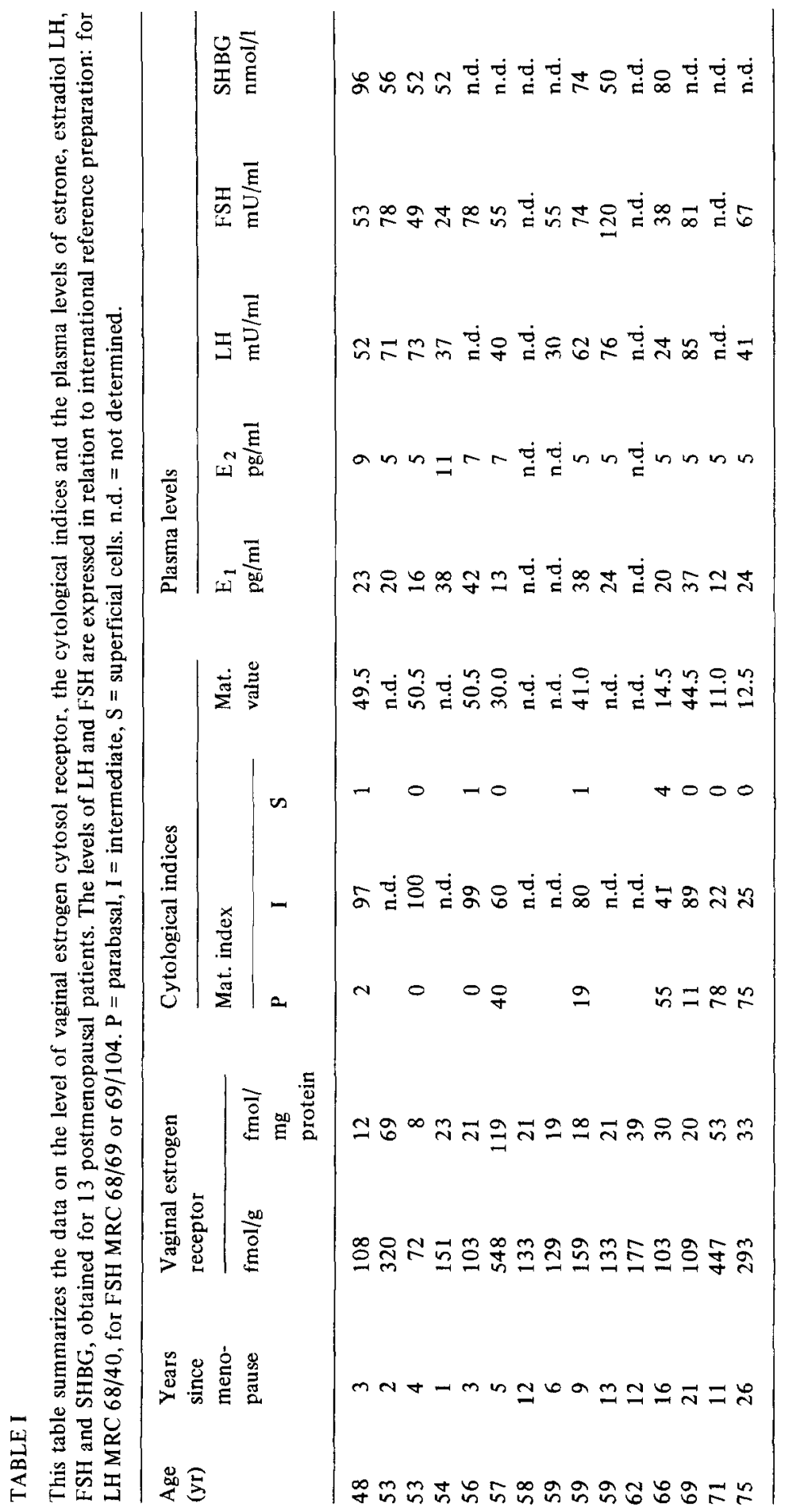


TABLE II

Distribution of estrogen receptors in the human vagina ( $\mathrm{fmol} / \mathrm{mg}$ protein).

\begin{tabular}{llllll}
\hline Patient & \multicolumn{2}{l}{ Anterior wall } & & Distal \\
\cline { 2 - 5 } & \multicolumn{2}{l}{ Proximal } & & & \\
\hline A & 53 & 36 & 43 & 65 & 49 \\
B & 9 & 11 & 10 & 12 & \\
\hline & Anterior & Posterior & & & \\
& wall & wall & & & \\
C & 27 & 28 & & & \\
D & 39 & 26 & & & \\
E & 37 & 14 & & & \\
\hline
\end{tabular}

16 premenopausal women the phase of the menstrual cycle at the time of operation could be classified hy endometrial histology. No significant difference in the vaginal estrogen receptor level was seen between 11 women with proliferative endometrium (mean level $30 \mathrm{fmol} / \mathrm{mg}$ protein) and 5 women with endometrium in the secretory phase (mean level $39 \mathrm{fmol} / \mathrm{mg}$ protein).

Table I summarizes the data on the estrogen-receptor concentration, the cytological indices and the plasma levels of endogenous estrogens, gonadotrophins and SHBG obtained for 15 postmenopausal women. The levels of estrone, estradiol, LH, FSH and SHBG are all within the normal range for that age-group. In the postmenopausal patients a significant negative correlation $(R=-0.72, P<0.05$, Spearman Rank Correlation Test) was found between the vaginal estrogen receptor level (in $\mathrm{fmol} / \mathrm{mg}$ protein) and the ma-

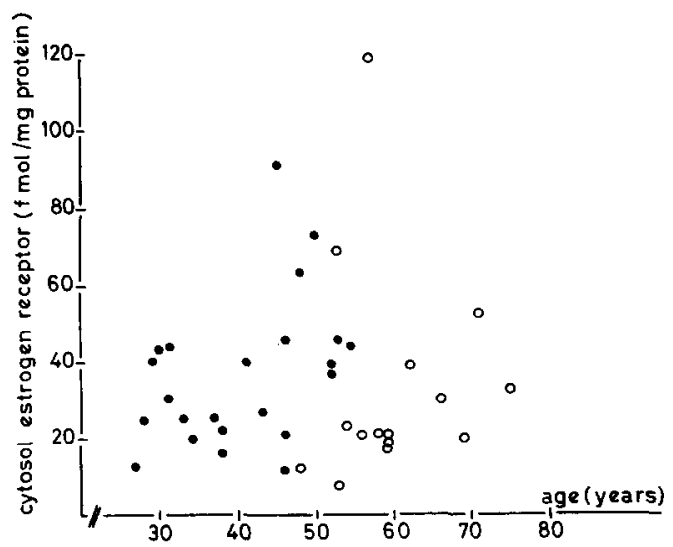

Fig. 3. The concentration of estrogen receptors in human vaginal tissue in 23 premenopausal and in 15 postmenopausal women is shown in relation to age. $\bullet$, premenopausal women; $\circ$, postmenopausal women. 
turation value of the vaginal smear. No correlations were found between the vaginal receptor level and the plasma levels of $E_{1}, E_{2}, L H, F S H$ and SHBG.

In two patients multiple tissue pieces of the vaginal wall ranging from the proximal to the distal part of the vagina were examined. In three patients the estrogen receptor concentration in the anterior and posterior vaginal wall was determined (Table II). No systematic differences in estrogen receptor concentration in various parts of the vagina were found.

In Figure 3, the estrogen receptor level is plotted against the age of the women. There is no correlation between the receptor level and age.

\section{DISCUSSION}

As far as we know, this study is the first to demonstrate and quantitate specific estrogen receptors in human vaginal tissue. This finding is not surprising because the human vagina is an estrogen-sensitive tissue. In accordance with the dogma of steroid hormone action, this should mean that this target tissue contains specific estrogen binding proteins which mediate the estrogenic effects. Our studies show, that the cytosol of human vaginal tissue contains such receptors which are characterized by high affinity for estradiol ( $K_{\mathrm{d}}$ about $1 \mathrm{nM}$, Fig. 1) and low capacity (in fmoles per mg protein). Sucrose gradient analysis shows that the receptor-estradiol-complex sediments as one peak in the about 4 S-region (Fig. 2). The radioactivity in this region could be abolished by an excess of cold estradiol or by an excess of nafoxidine, which is a specific competitor of the bind. ing of estradiol to its receptor. Part of the vaginal tissues studied were from patients with a mild degree of cystocele or rectocele. We cannot exclude that this type of disorder could have been of influence on our results.

Our results are in agreement with the studies on the uptake of tritated estradiol by vaginal slices in vitro [15] and with the intracellular uptake of radioactive estradiol measured by autoradiographic techniques $[16,17]$.

Stumpf et al. [16] found with autoradiographical techniques a higher concentration of estradiol in parabasal cells as compared to intermediate cells and negligible quantities in superficial layers.

The negative correlation between the estrogen receptor level (in $\mathrm{fmol} / \mathrm{mg}$ protein) and the vaginal maturation value might be explained by assuming the highest concentration of estrogen receptors in the parabasal cells. In an atrophic vagina the tissue sample will contain many parabasal cells resulting in a relatively high estrogen receptor concentration, whereas the maturation value will be low by lack of superficial and intermediate cells. In well proliferated vaginal epithelium a considerable part of the tissue sample will consist of superficial and intermediate cells with smaller numbers of parabasal cells, reducing the level of estrogen receptor per weight unit while the maturation value will be high due to the presence of many superficial and intermediate cells.

We found no correlation between the concentration of estrogen cytosol receptors in the vagina and the age of the women. This is in contrast to the findings in human myometrial cytosol in which a significantly higher concentration of estradiol receptors was found in postmenopausal women compared to premenopausal women, irrespective of the phase of the menstrual cycle $[4,18]$. In endometrium a relatively high estradiol cytosol 
binding was demonstrated in postmenopausal women equal to values in premenopausal women in the proliferative phase of the cycle. The highest concentration of estradiol receptors was found in early proliferative endometrium, the lowest in the disintegrating secretory phase [4]. We were unable to show such a relationship in the vaginal cytosol.

The vaginal cytosol estrogen receptor concentration in postmenopausal women has a mean value of $34 \mathrm{fmol} / \mathrm{mg}$ protein ( $n=15$, range $8-119 \mathrm{fmol} / \mathrm{mg}$ protein), for less than found [4] in postmenopausal endometrium (mean $112 \mathrm{fmol} / \mathrm{mg}$ protein, $n=16$, range 66-181 fmol/mg protein) and postmenopausal myometrium (mean $100 \mathrm{fmol} / \mathrm{mg}$ protein, $n=3$, range $93-106 \mathrm{fmol} / \mathrm{mg}$ protein).

In postmenopausal women the amount of endogenous estrogens needed to develop or maintain proliferation of the vaginal epithelium is lower than that needed for proliferation of the endometrium [19]. It is surprising, that a highly sensitive estrogen target tissue as vagina has a relatively low estrogen receptor level. Our work was restricted to the cytosol receptors. Nuclear binding of estrogens was not estimated. Whether the low cytosol level of estrogen receptors reflects a higher translocation of the cytosol receptor to the nucleus, even in the presence of a low level of endogenous estrogens in the plasma, is unclear. There still remains the possibility that local intracellular factors influence the efficiency of the receptor mechanism and, therefore, the degree of expression of the hormonal response in a positive or negative direction.

Differences in such local factors between endometrium, myometrium and vagina may determine the sensitivity of the tissue to estrogens and possibly explain the observed differences in sensitivity. Studies on the presence of such local factors in several target tissues are in progress in our laboratory.

\section{ACKNOWLEDGEMENTS}

We thank Prof. Dr. A.A. Haspels and Prof. Dr. F. Schwarz for their stimulating interest and critical reading of the manuscript. We are grateful for the technical assistance of Mrs. I. Borgart-Creutzburg, for the cooperation of the clinical staff of the department of Obstetrics and Gynecology and the technicians of the department of Cytology (head: drs. G. Linthorst). We thank Ms. A. de Rooy for the secretarial work involved in the preparation of this manuscript.

\section{REFERENCES}

[1] Robertson, D.M., Mester, J., Beilby, J., Steele, S.J. and Kellie, A.E. (1971) The measurement of high affinity oestradiol receptors in human uterine endometrium and myometrium. Acta Endocrinol. (KBH) $68,534-542$.

[2] Trams, G., Engel, B., Lehmann, F. and Maass, H. (1973) Specific binding of oestradiol in human uterine tissue. Acta Endocrinol. 72, 351-360.

[3] Crocker, J.G., Milton, P.J.D. and King, R.J.B. (1974) Uptake of $\left(6,7.3^{3} \mathrm{H}\right)$ oestradiol-1 7 by normal and abnormal human endometrium. J. Endocrinol. 62, 145.

[4] Evans, L.H., Martin, J.D. and Hähnel, R. (1974) Estrogen receptor concentration in normal and pathological human uterine tissues. J. Clin. Endocrinol. Metabol. 38, 23-32.

[5] Pollow, K., Pollow, B. and Schmidt-Gollwitzer, M. (1978) Estrogen receptor in normal human endometrium and in endometrial carcinoma. J. Mol. Med. 3, 71-79. 
[6] Van Kammen, E., Thijssen, J.H.H., Rademaker, B. and Schwarz, F. (1975) The influence of hormonal contraceptives on sex-hormone-binding globulin (SHBG) capacity. Contraception 11, 53-59.

[7] Meisels, A. (1967) The maturation value. Acta Cytol. 11, 249.

[8] Scatchard, G. (1949) The attraction of proteins for small molecules and ions. Ann. NY Acad. Sci. 51, 660-671.

[9] Poortman, J., Prenen, J.A.C., Schwarz, F. and Thijssen, J.H.H. (1975) Interaction of 5-Androstene-3,17-diol with estradiol and dihydrotestosterone receptors in human myometrial and mammary cancer tissue. J. Clin. Endocrinol. Metabol. 40, 373-379.

[10] Siiteri, P.K., Schwarz, B.E., Moriyama, L., Ashby, R., Linkie, D. and MacDonald, P.D. (1973) Estrogen binding in the rat and human. In: Receptors for reproductive hormones. Advances of Experimental Medicine and Biology 36, pp. 97-113. Editors: B.W. O'Malley and A.R. Means. Plenum Press, New York.

[11] Lowry, O.H., Rosebrough, N.J., Farr, A.L. and Randall, R.J. (1951) Protein measurement with the folin phenol reagent. J. Biol. Chem. 193, 265-275.

[12] Van Paassen, H.C., Poortman, J., Borgard-Creutzburg, I.H.C., Thijssen, J.H.H. and Duursma, S.A. (1978) Oestrogen binding proteins in bone cell cytosol. Calc. Tiss. Res. 25, 249-254.

[13] Thijssen, J.H.H., Poortman, J. and Schwarz, F. (1975) Androgens in postmenopausal breast cancer: excretion, production and interaction with estrogens. J. Ster. Biochem. 6, 729-734.

[14] McGuire, W.L., de la Garza, M. and Chamness, G.C. (1977) Evaluation of estrogen receptor assays in human breast cancer tissue. Canc. Res. 37, 637-639.

[15] Brush, M.G., Taylor, R.W. and King, R.J.B. (1967) The uptake of $\left(6,7-{ }^{3} \mathrm{H}\right)$ oestradiol by the normal human female reproductive tract. J. Endocrinol. 39, 599-607.

[16] Stumpf, W.E., Baerwaldt, C. and Sar, M. (1971) Autoradiographic cellular and subcellular localisation of sexual steroids. In: Basic actions of sex steroids on target organs, pp. 3-20. Editors: P.O. Hubinont, F. Leroy and P. Galand. Karger, Basel.

[17] Bartizal, F.J., Coulam, C.B., Gaffey, T.A., Ryan, R.J. and Riggs, B.L. (1975) Impaired binding of estradiol to vaginal mucosal cells in postmenopausal osteoporosis. In: Proceedings of the XIth European Symposium on Calcified Tissues, pp. 412-416. Editors: S. Pors Nielsen and E. HjфrtinHansen. Fadl's Forlag, Copenhagen.

[18] Pollow, K., Geilfuss, J., Boquqi, E. and Pollow, B. (1978) Estrogen and progesteron binding proteins in normal human myometrium and leiomyoma tissue. J. Clin. Chem. Clin. Biochem. 16, $503-511$.

[19] Spcroff, L., Glass, R.H. and Kase, N. (1975) Clinical gynecologic Endocrinology and Infertility, pp. 45-46. The Williams and Wilkins Company, Baltimore. 